University of Nebraska - Lincoln

DigitalCommons@University of Nebraska - Lincoln

$9-27-2018$

\title{
Forage Potential of Summer Annual Grain Legumes in the Southern Great Plains
}

\author{
Gurjinder S. Baath \\ Oklahoma State University, gbaath@okstate.edu \\ Brian K. Northup \\ Oklahoma State University \\ Alexandre C. Rocateli \\ Oklahoma State University \\ Prasanna H. Gowda \\ Oklahoma State University \\ James P. S. Neel \\ Oklahoma State University
}

Follow this and additional works at: https://digitalcommons.unl.edu/usdaarsfacpub

Baath, Gurjinder S.; Northup, Brian K.; Rocateli, Alexandre C.; Gowda, Prasanna H.; and Neel, James P. S., "Forage Potential of Summer Annual Grain Legumes in the Southern Great Plains" (2018). Publications from USDA-ARS / UNL Faculty. 2137.

https://digitalcommons.unl.edu/usdaarsfacpub/2137

This Article is brought to you for free and open access by the U.S. Department of Agriculture: Agricultural Research Service, Lincoln, Nebraska at DigitalCommons@University of Nebraska - Lincoln. It has been accepted for inclusion in Publications from USDA-ARS / UNL Faculty by an authorized administrator of DigitalCommons@University of Nebraska - Lincoln. 


\title{
Forage Potential of Summer Annual Grain Legumes in the Southern Great Plains
}

\author{
Gurjinder S. Baath,* Brian K. Northup, Alexandre C. Rocateli, Prasanna H. Gowda, and James P. S. Neel
}

\section{ABSTRACT}

Winter wheat (Triticum aestivum L.) and perennial warm-season grasses are the primary forage resources for grazing yearling stocker cattle (Bos taurus) in the US Southern Great Plains (SGP). However, low nutritive value of perennial grasses during mid to late summer limits high rates of growth by stocker cattle. In response, there has been a continued search for plant materials with the potential to provide forage high in crude protein (CP) and digestibility during August through September. A broad range of under-utilized legume species that are grown as grain crops in Africa, India, and South and Central America may have some capacity to serve as high quality pasture or harvested forage in the SGP. However, any crop selection must account for limitations related to unpredictable summer rainfall amounts and patterns, and the frequent occurrence of prolonged drought. Further, any selection should not create water deficits for following winter wheat, the primary forage and grain crop in the region. This article summarizes a small subset of the broad range of underutilized grain legumes (pulses) which exist worldwide and soybean [Glycine $\max$ (L.) Merr.] that may have capacity to serve as high quality forage for late-summer grazing. Bringing these crops into forage-stocker production systems could improve the overall system effectiveness, in addition to providing other ecosystem services (e.g., ground cover, grain crops).

\section{Core Ideas}

- Forage quality gap during mid through late summer affects stocker cattle production.

- A broad range of under-utilized grain legumes may serve as highquality forages.

- Adoption of such crops could enhance sustainability of stockerbased grazing systems.

\section{1}

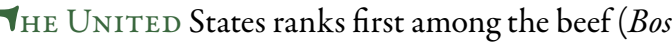
taurus) producing countries and accounted for approximately $18.2 \%$ of global production of beef in 2013 (FAO, 2017). Although there has been a decline in per capita beef consumption within the United States (from $33.8 \mathrm{~kg}$ in 1985 to $25.3 \mathrm{~kg}$ in 2016), total consumption (about 11.6 billion $\mathrm{kg}$ ) has continually increased due to population growth (Kannan et al., 2017). Cattle production accounted for approximately $\$ 60$ billion in total agricultural sales and was the largest among US agricultural commodities, followed by $\$ 49$ billion from maize (Zea mays L.) sales in 2015 (USDA-NASS, 2016). The United States exported about $\$ 6.3$ billion in beef products to Japan, South Korea, Mexico, Canada, Hong Kong, and other countries in 2015 (USDA-ERS, 2017a).

Agriculture in the Southern Great Plains (SGP) is equally important to global, national, and regional food security, particularly the beef production system that developed during the late 20th century. Annually, millions of weaned calves from cowcalf operations throughout the United States are sold through local markets (Peel, 2003). Most of these animals are eventually feedlot finished in the SGP and processed at co-located slaughter and packer facilities (Fig. 1). However, there is insufficient feedlot space to accommodate all these animals simultaneously, so large numbers spend time grazing pasture in the SGP as stocker cattle, generating low-cost gain until space becomes available (Peel, 2003). Texas, Kansas, and Oklahoma represent the majority of the SGP region and are among the top five beef producing states (Fig. 1), which further outlines the importance of the region to beef production.

The SGP is comprised of diverse land types including native range, introduced perennial grasses, dryland cropping, and irrigated areas. It spreads from the front range of the Rocky Mountains in Colorado and New Mexico, eastward through Oklahoma and southern Kansas (Fig. 1). The periphery swings across northwest Texas to the southern limit of New Mexico through the Texas Panhandle and adjoining areas of west Texas and eastern New Mexico. Elevation in the region ranges from 1500 to $1800 \mathrm{~m}$ at the western edge to $<600 \mathrm{~m}$ on the eastern and southern edges (Savage and Costello, 1948). The amount and timing of precipitation received annually in the SGP varies

G.S. Baath, A.C. Rocateli, Dep. of Plant and Soil Sciences, Oklahoma State Univ., 371 Agricultural Hall, Stillwater, OK 74078; B.K. Northup, P.H. Gowda, J.P.S. Neel, USDA-ARS, Grazinglands Research Lab., 7207 W. Cheyenne St., El Reno, OK 73036. Received 18 Dec. 2017. Accepted 6 Aug. 2018. ${ }^{*}$ Corresponding author (gbaath@okstate.edu).

Abbreviations: ADF, acid detergent fiber; CP, crude protein; IVDDM, in vitro digestible dry matter; NDF, neutral detergent fiber; SGP, Southern Great Plains. 

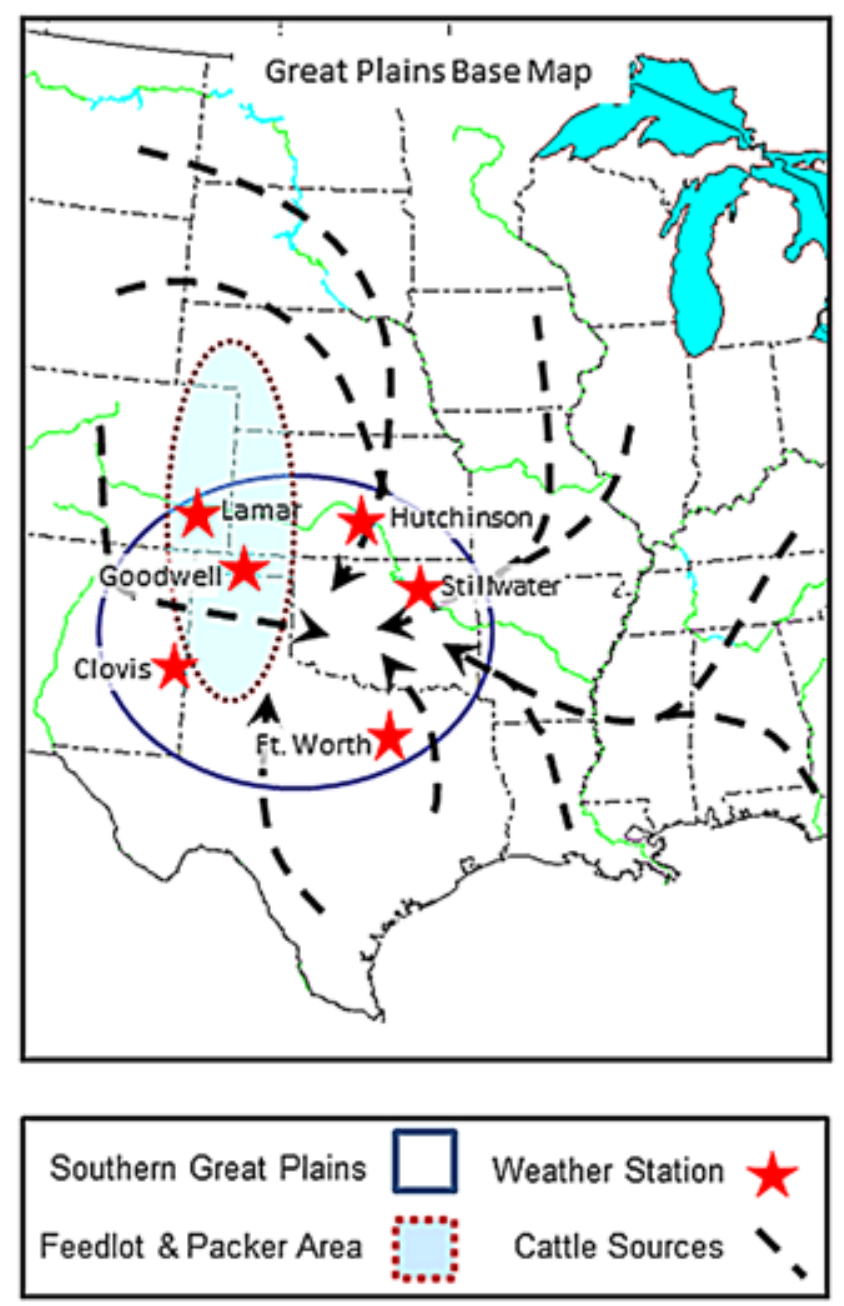

Fig. I. Location of the southern Great Plains (SGP), sources of cattle that graze in the region in route to feedlots, and the area with large concentration of feedlots and co-located packers.

throughout the region, ranging from 395 to $449 \mathrm{~mm}$ in the western areas to 755 to $890 \mathrm{~mm}$ along the eastern fringe (Fig. 1 and 2). About half of the total annual rainfall occurs during late-spring through summer (May-September). However, the region frequently encounters prolonged periods of drought, where amount and occurrence of rainfall during this period is erratic on a monthly basis (Schneider and Garbrecht, 2003; Rao and Northup, 2011a; Patrignani et al., 2014). Maximum air temperatures are relatively uniform with low levels of variability $\left(29.5-33^{\circ} \mathrm{C}\right)$, particularly during June through August (Fig. 3). Minimum air temperatures are more variable $\left(14-21^{\circ} \mathrm{C}\right)$ during summer. The level of variability in precipitation and temperature within the SGP presents a challenge for defining new crops with the potential to function on a region-wide basis.

The dominant elements of forage systems that support weight gain by yearling stocker cattle in the SGP utilize annual winter wheat (Triticum aestivum L.) and perennial (native prairie or introduced) warm-season grasses (Phillips and Coleman, 1995; Redmon et al., 1995; Peel, 2003). These systems (Fig. 4) have been effective for grazing yearling stocker cattle but with shortcomings related to limited availability of high-quality forage in May and from August through October (Phillips and Coleman, 1995; Coleman and Forbes, 1998; Northup et al., 2007). Combinations of forages arrayed in larger systems are required

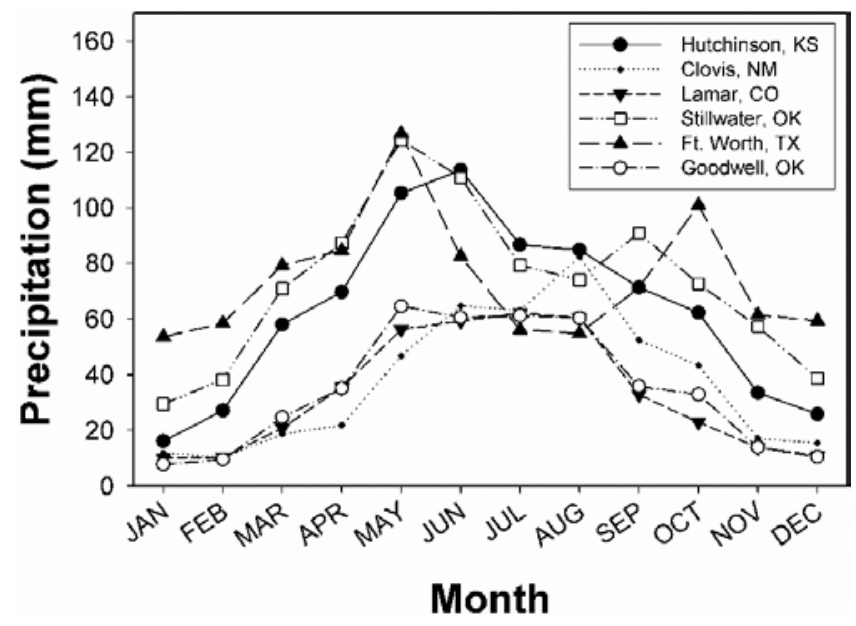

Fig. 2. Long-term (1966-20I6) average monthly precipitation for six locations within the US Southern Great Plains (SGP).

to lengthen the time that high-quality forage is available and limit shortcomings during the production cycle (Northup et al., 2007; Phillips et al., 2009; Patrignani et al., 2014).

Winter wheat is also the primary agricultural crop planted in the SGP region, with more than 2.6 million ha planted annually in Oklahoma (Hossain et al., 2004). It serves producers as a drought avoidance crop, by taking advantage of soil moisture that accumulates during summer fallow (June-August) and September rainfall, and matures early enough to avoid the hot and dry conditions that occur during summer. Summer fallow serves as a technique to minimize risk of crop failure. Aiken et al. (2013) reported 18 and $31 \%$ reductions in wheat forage and grain yields, respectively, due to $132 \mathrm{~mm}$ less soil water in wheat-soybean [Glycine $\max (\mathrm{L}$.) Merr.] rotations compared with wheat-fallow rotations in western Kansas. However, there are numerous sustainability issues for wheat-fallow rotations, including poor precipitation use efficiency (Farahani et al., 1998), potentially greater soil erosion, and decreased soil organic $\mathrm{C}$ and $\mathrm{N}$, depending on tillage system (Kelley and Sweeney, 2010). No-till systems can help alleviate such problems, but there has been limited adoption by wheat producers in the region. For example, a survey in Oklahoma (Hossain et al., 2004) reported roughly $89 \%$ of producers who use continuous winter wheat-summer fallow systems apply conventional tillage to $56 \%$ of the total area planted to wheat, while 36 and $8 \%$ of cropland is managed by reduced and no-till systems, respectively (Conservation Technology Information Center, 2004).

Wheat is a dynamic and flexible crop capable of producing multiple commodities within one growing season, based on its competing values as grain, hay, and livestock gain (Peel, 2003; Decker et al., 2009; Edwards et al., 2011). Wheat serves as the primary source of high-quality forage for stocker cattle from late fall through early spring (Fig. 4). According to a survey in Oklahoma (Hossain et al., 2004), the intended use of winter wheat was $20 \%$ for pasture only, $49 \%$ for a dual-purpose role (winter grazing and spring grain), and $31 \%$ for production of grain only. Wheat grown for grain is planted during late September through early October to avoid the potential occurrence of dry growing conditions in early September (Lyon et al., 2007). Alternatively, dual-purpose wheat (graze-grain) is generally planted in early to mid-September and grazed from mid-November until the occurrence of first 


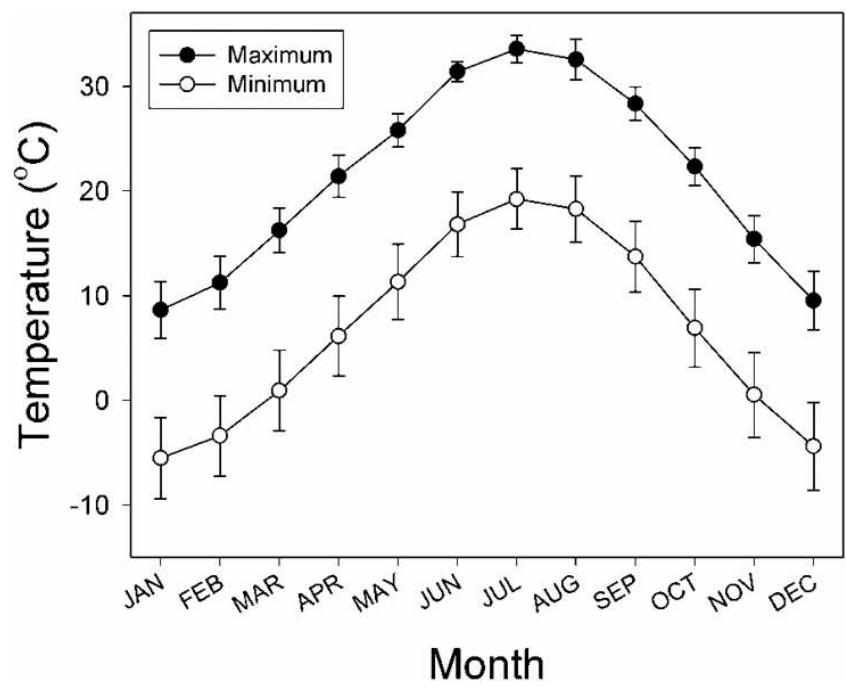

Fig. 3. Long-term (1966-2016) average monthly maximum and minimum air temperatures of six locations within the US Southern Great Plains (SGP). Error bars indicate standard deviation.

hollow stem (early March) stage of growth (Fieser et al., 2006; Edwards et al., 2011). Wheat grown for grazed pasture (grazeout) is planted in early September, to maximize forage production during November through April (Fig. 4).

Pasture of perennial warm-season grasses including bermudagrass [Cynodon dactylon (L.) Pers.], Old World bluestems (Bothriochloa spp.), and native prairie have been the traditional forages for summer grazing, though mostly in support of cow-calf operations (Fig. 4; Phillips and Coleman, 1995; Coleman and Forbes, 1998; Rao et al., 2002). In contrast to cow-calf pairs, production of stocker cattle requires a large amount of high-quality forage to fulfill both growth and maintenance requirements of animals (Phillips and Coleman, 1995; Neel et al., 2007). An important issue for grazing stocker cattle is the decline in forage quality of these perennial grasses with maturation as the growing season advances (Coleman and Forbes, 1998). This decline becomes a limiting factor for stocker production without protein supplementation (Phillips and Coleman, 1995; NRC, 1996). Given the growth patterns of winter wheat and the more typical perennial warm-season grasses, there is no single forage crop capable of providing nutritious biomass for year-round grazing. A possible solution is to find nutritious forages that can fill the void during mid-summer and enhance sustainability of forage-stocker systems. However, any such potential crops must also perform well within the widely adopted systems used in production of the primary crop of the SGP (winter wheat) without generating deficits in soil resources that are important to establishment and growth by winter wheat (Rao and Northup, 2009b).

Work undertaken over the last two decades in the SGP has searched for annual grain legumes (pulses) with potential to serve as either forages or green manures (Rao et al., 2005; Rao and Northup, 2009a, 2011b; Butler and Muir, 2012; Northup and Rao, 2015, 2016). Some of the tested pulses showed potential to provide high-N biomass (Rao and Northup, 2009a, 2012, 2013; Northup and Rao, 2015). However, the presence of large diameter, low quality stems limits the value of many pulses for grazing (Rao and Northup, 2013). Further, the biomass of many species contains secondary plant compounds, especially tannins and other polyphenolics (Price et al., 1980; Kumar and Singh, 1984; Ajayi et

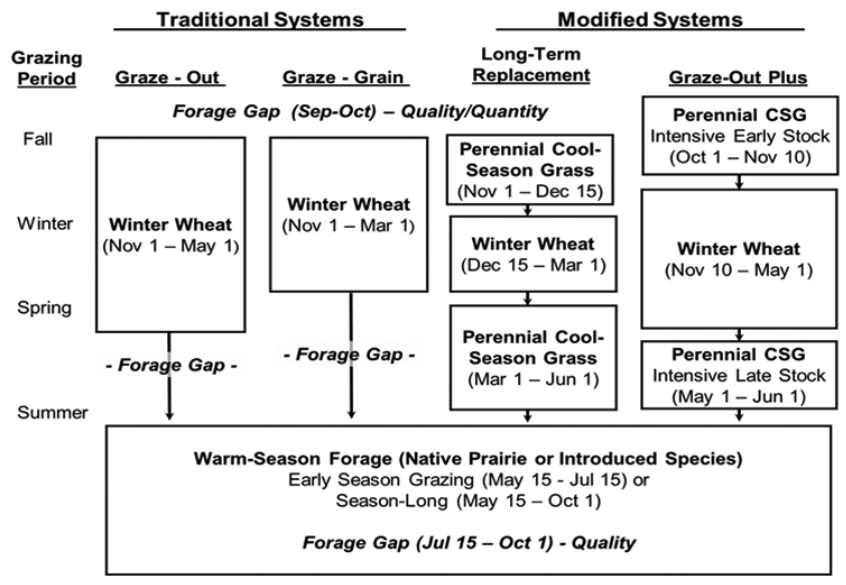

Fig. 4. Gaps in available traditional winter wheat-summer forage systems in the SGP.

al., 2009). Both factors restricted grazing to short time periods of the lifecycle of the tested pulses (Rao and Northup, 2012). Such issues and limitations for the tested legumes indicate there is still a need for research to identify alternate species of pulses that may serve as sources of high $\mathrm{N}$ biomass for agroecosystems in the SGP.

Worldwide, roughly 7000 plant species are cultivated to feed humans. However, just 20 species meet $90 \%$ of the total food requirements for humans (Chivenge et al., 2015). The remaining species are underutilized or their use is restricted to limited areas such as sub-Saharan Africa. Such a large pool means there is a diverse range of underutilized crops that may have the capacity to provide grazing or hay for cattle in the SGP. Identifying welladapted legume species from such a broad base of crops for use as forage in stocker production systems of the SGP could enhance the sustainability of stocker-based grazing systems, or increase agro-ecosystem diversity by providing new cover or grain crops.

Selection of the proper crop for summer periods will be critical due to the agro-climatic conditions in the SGP. Most crops tend to function better in systems with greater amounts of available water due to reduced competition for this limited resource (Snapp et al., 2005). However, competition for moisture between summer crops and subsequent winter wheat in the SGP needs addressing, as irrigation is not an option for most producers in the region. The performance of dryland winter wheat, particularly during the period of germination and early fall growth, relies on moisture stored in the soil profile (Rao and Northup, 2011b). Therefore, the emphasis should be on identifying crops that are productive in response to the variable climate of the SGP, and have limited effects on soil moisture to minimize carryover effects on subsequent wheat crops. This review discusses soybean, the most commonly used legume in the SGP, and some species of pulses from arid and semiarid regions that might fit the forage-livestock production systems of the SGP as summer forage.

\section{SOYBEAN}

Soybean, an oilseed legume species, originated and was domesticated in south China (Guo et al., 2010). It is widely grown across many parts of the world. Soybean has an erect growth habit and can grow to a height of $1.3 \mathrm{~m}$ (Lee et al., 1996). Cultivated soybean plants have trifoliate leaves with oval to lanceolate leaflets and purple, pink, or bluish papilionaceous flowers. It has a well-developed taproot system, which can extend 
to a depth of $1.5 \mathrm{~m}$ (Ordóñez et al., 2018). The United States is currently the largest producer (35\% of world production) of soybean, followed by Brazil (29\%) and Argentina (17.5\%) (FAO, 2017; Ciampitti and Salvagiotti, 2018). Within the United States, 31 states produce soybean with Illinois, Iowa, Minnesota, and Indiana as the top four producers (USDA-NASS, 2017)

Soybean is largely grown for grain, which has multiple uses. Raw soybean contains $360 \mathrm{~g} \mathrm{~kg}^{-1}$ protein, $300 \mathrm{~g} \mathrm{~kg}^{-1}$ carbohydrates, $200 \mathrm{~g} \mathrm{~kg}^{-1}$ fat, and many essential vitamins and minerals (USDA-ARS, 2016) and serves as an important component in the diets of vegetarians and vegans across the world. The consumption of soybean foods has continuously increased in the last few decades due to its health benefits, including prevention of cancer, obesity, and diabetes, lowering of cholesterol, and protection against kidney and bowel disease (Friedman and Brandon, 2001). Further, soybean oil is currently a leading feedstock for biodiesel production in the United States and considered as an effective and economical component in products such as paints, resins, rubber, polyurethane, and coatings.

Within soybean, variation in the daylength, which initiates the physiological transition from vegetative to reproductive stages, results in cultivars being classified into different maturity groups (Zhang et al., 2017). It generally takes 100 to $120 \mathrm{~d}$ to reach maturity with mid-late maturity group cultivars in the SGP (Rao and Northup, 2009a; Wagle et al., 2017). The late maturity group cultivars produce greater forage biomass during September-October than other cultivars in the SGP (Rao et al., 2005). Soybean requires a temperature range of 25 to $30^{\circ} \mathrm{C}$ for an optimum growth, and its reproduction is affected at temperatures above $35^{\circ} \mathrm{C}$ (Salem et al., 2007; Setiyono et al., 2007). The total water requirement of soybean ranges from 420 to 540 $\mathrm{mm}$ in the Midwest region of United States (Payero et al., 2005; Suyker and Verma, 2009).

Soybean was primarily grown as a forage crop after its introduction into the United States in the mid-19th century (Probst and Judd, 1973). However, grain land area surpassed forage land area by 1941 due to the demand for its oil and meal. In the last two decades, there has been renewed interest by researchers in evaluating soybean as a forage crop in the United States (Sheaffer et al., 2001; Rao and Northup, 2008; Nielsen, 2011; Beck et al., 2017). In the SGP, forage yields of soybean ranged between 1.1 and $5.4 \mathrm{Mg} \mathrm{ha}^{-1}$ with 150 to $190 \mathrm{~g} \mathrm{~kg}^{-1} \mathrm{CP}$ and 740 to $790 \mathrm{~g} \mathrm{~kg}^{-1}$ in vitro digestible dry matter (IVDDM; Rao et al., 2005; MacKown et al., 2007; Rao and Northup, 2009a; Northup and Rao, 2015). It was found to produce insufficient biomass $\left(<1.5 \mathrm{Mg} \mathrm{ha}^{-1}\right)$ in the years receiving low precipitation (<50 mm) during early summer (Rao and Northup, 2009a; Foster et al., 2009; Northup and Rao, 2015), which would cause limitations on forage intake by yearling cattle (Coleman et al., 2010). Double-cropping winter wheat and soybean is an important practice in many regions across the United States (Knott et al., 2018). However, when the approach was investigated by MacKown et al. (2007) and Northup and Rao (2015) in the SGP, it was found to be ineffective. Given the variability associated with spring and summer rainfall patterns in the SGP, productivity of double-cropped soybean as forage was reported as marginal (1.17 $\left.\mathrm{Mg} \mathrm{ha}^{-1}\right)$, and the function of soybean as a green manure failed to offer any $\mathrm{N}$ benefit to winter wheat or increase
$\mathrm{C}$ and $\mathrm{N}$ concentrations after 3 to $4 \mathrm{yr}$ (MacKown et al., 2007; Northup and Rao, 2015).

\section{TEPARY BEAN}

Tepary bean [Phaseolus acutifolius (A.) Gray] is an annual legume native to northwestern Mexico and the southwestern United States. Cultivated tepary bean plants have either bush or semi-vine type growth forms, with pointed trifoliate leaves, short and slightly hairy green pods, and deep tap root systems (Stephens, 1994). Tepary bean was once a vital part of the "Native American diet" in its home range and was specially honored at the 1912 International Dry Bean Congress for its flavor and reliable yields in rainfed cropping systems (Bhardwaj et al., 2002). However, the spread and development of tepary bean stayed limited to specific forms of dryland farming due to irrigation developments and restricted marketing in the southwestern United States (Porch et al., 2013). It has been receiving increased attention from researchers for adaptability to dry conditions and as a genetic donor to improve drought tolerance in common bean (Phaseolus vulgaris L.) (Pratt, 1983; Singh and Munoz, 1999; Rainey and Griffiths, 2005).

On the African continent, tepary bean has been recognized as an important food crop to combat malnutrition and enhance income and livelihoods of resource-limited farmers in many countries, including Kenya and Zimbabwe (Jiri and Mafongoya, 2016). Small farmers in Botswana grow tepary bean for food and utilize the haulms (stems) as feed for animals (Molosiwa et al., 2014).

One of the nutritional feature of all bean plants is the presence of large amounts of protein and fiber in their seed. Grain of tepary bean has high protein $\left(240 \mathrm{~g} \mathrm{~kg}^{-1}\right)$ and iron $\left(0.1 \mathrm{~g} \mathrm{~kg}^{-1}\right)$ concentrations (Bhardwaj and Hamama, 2004). The bean contains $18 \mathrm{~g} \mathrm{~kg}^{-1}$ oil with $330 \mathrm{~g} \mathrm{~kg}^{-1}$ saturated and $670 \mathrm{~g} \mathrm{~kg}^{-1}$ unsaturated fatty acids. Among the unsaturated fatty acids, $240 \mathrm{~g} \mathrm{~kg}^{-1}$ are monounsaturated, and $420 \mathrm{~g} \mathrm{~kg}^{-1}$ are polyunsaturated (Bhardwaj and Hamama, 2005). Apart from its high nutritional value, tepary bean has been reported to have some medicinal value. They possess unique characteristics to combat diabetes and treat the development of cancer (Garcia-Gasca et al., 2002).

Tepary bean is a suitable crop for hot and dry environments. It requires a temperature range of 25 to $35^{\circ} \mathrm{C}$ for optimum germination and has a minimum requirement of $8^{\circ} \mathrm{C}$ for its vegetative growth (Scully and Waines, 1987, 1988). Miklas et al. (1994) reported a grain yield of 770 to $1640 \mathrm{~kg} \mathrm{ha}^{-1}$ across an array of environments in Central America with a precipitation range of 164 to $396 \mathrm{~mm}$ during a growing season and average minimum and maximum temperature ranges of 16.1 to $22.8^{\circ} \mathrm{C}$ and 29.3 to $32.5^{\circ} \mathrm{C}$, respectively. In addition, tepary bean seems to improve the soil fertility through biological $\mathrm{N}$ fixation (Shisanya, 2002). Bhardwaj et al. (2002) grew tepary bean successfully as a short-duration summer crop in rotation with winter wheat in Virginia, which has more humidity and precipitation than the SGP. Markhart (1985) reported that tepary bean tolerates drought better than common bean by closing its stomata at a much higher water potential when exposed to water stress. It is found to be highly tolerant of heat, salinity, many diseases, and insects (Miklas et al., 1994; Miklas and Santiago, 1996; Pratt et al., 1990). 
Tepary bean has exhibited great potential for forage production, though published literature is limited. Bhardwaj (2013) reported fresh and dry yields of 22.2 and $4.4 \mathrm{Mg} \mathrm{ha}^{-1}$, respectively, at $59 \mathrm{~d}$ after planting on a sandy loam soil in eastern Virginia. Forage quality of tepary bean reported in this study appears to be comparable with alfalfa and soybean forage in terms of CP; however, it had greater fiber concentrations (Table 1).

Tepary bean may fit well within the management systems applied to winter wheat in the SGP due to its drought tolerance and relatively short life cycle of around 60 to $75 \mathrm{~d}$ (Tinsley et al., 1985). The limited amount of information also indicated tepary been might provide much needed nutritious forage during the late-summer period (Bhardwaj, 2013). Grazing or one cutting for hay with subsequent plow down would be a possible method of management. Further, lines that have semi-vine growth forms may also have value as cover crops. However, due to the lack of field studies, more research is required to evaluate its feasibility as a forage crop in the SGP.

\section{MOTHBEAN}

Mothbean [Vigna aconitifolia (Jacq.) Marechal] is an annual summer legume, cultivated mainly in the semiarid and arid regions of India due to its high drought and heat tolerance. Mothbean is a short-duration crop with a 60- to 75-d lifespan (Kumar and Rodge, 2012). Optimum production can be achieved within a temperature range of 24 to $32^{\circ} \mathrm{C}$, but mothbean can tolerate daytime temperatures up to $45^{\circ} \mathrm{C}$ (Vijendra et al., 2016). Water requirements of mothbean during a growing season are quite low, ranging between 190 and $260 \mathrm{~mm}$ in its native regions (Rao and Poonia, 2011). Singh et al. (2000) estimated an evapotranspiration rate of 1.8 to $2.2 \mathrm{~mm} \mathrm{~d}^{-1}$ and $4.8 \mathrm{~mm} \mathrm{~d}^{-1}$, respectively, during early vegetative and reproductive growth stages. Therefore, it has the potential to perform well in environments with low and erratic amounts of rainfall (Narain et al., 2001), which is a regular feature of summer precipitation in the SGP. The wide adaptability of mothbean enables it to grow on sand dunes or other marginal lands with slight salinity and a wide $\mathrm{pH}$ (3.5-10) range (Manga et al., 2015; Vijendra et al., 2016).

Mothbean serves as a multipurpose crop in its native range as a source of food, forage, and green manure (Manga et al., 2015). Mothbean seeds are rich in protein $\left(230 \mathrm{~g} \mathrm{~kg}^{-1}\right)$ and contain some essential amino acids, minerals, carbohydrates, fiber, and vitamins (Siddhuraju et al., 1994; USDA-ARS, 2016). Although it is mainly grown in arid or desert regions of India, it seems to be adaptable to a broad range of climatic conditions. Research over 100 yr ago (Conner, 1908) reported a yield (fresh wt.) of $4.4 \mathrm{Mg} \mathrm{ha}^{-1}$ in northwestern Texas when planted at a 90-cm row spacing; no seed set was recorded at that location. Kennedy and Madson (1925) reported yields (fresh wt.) of 45 and $60 \mathrm{Mg} \mathrm{ha}^{-1}$, respectively, when planted at a $90-\mathrm{cm}$ row spacing under irrigated and dryland conditions near Fresno, CA. The given explanation for greater yield in dryland conditions was good condition of the seed bed at planting, which resulted in a better stand than under irrigated conditions. They also reported an average seed yield of $198 \mathrm{~kg} \mathrm{ha}^{-1}$ from a mothbean study conducted near Davis, CA. Bhardwaj and Hamama (2016) reported seed yields of mothbean varied from 55 to 468 $\mathrm{kg} \mathrm{ha}^{-1}$ in a test of 54 accessions in the eastern United States. In central Oklahoma, a preliminary study involving 10 mothbean
Table I. Comparison of forage quality of tepary bean with alfalfa hay and forage soybean.

\begin{tabular}{|c|c|c|c|c|}
\hline \multirow[b]{2}{*}{ Forage } & \multicolumn{3}{|c|}{ Forage quality traits } & \multirow[b]{2}{*}{ Citation } \\
\hline & $\mathrm{CP}$ & ADF & NDF & \\
\hline & & $\mathrm{g} \mathrm{kg}^{-1}$ & & \\
\hline Tepary bean & 214 & 375 & $4 I I$ & Bhardwaj, 2013 \\
\hline Alfalfa hay & 200 & 303 & 365 & LaCasha et al., 1999 \\
\hline Forage soybean & 192 & 293 & 407 & Hintz et al., I 992 \\
\hline
\end{tabular}

lines reported a dry forage yield of 7.3 to $18.1 \mathrm{Mg} \mathrm{ha}^{-1}$ and grain yield of 0.1 to $1.0 \mathrm{Mg} \mathrm{ha}^{-1}$ on harvesting mothbean at $100 \mathrm{~d}$ after planting (Baath et al., 2018). The same study reported that mothbean forage possessed 110 to $150 \mathrm{~g} \mathrm{~kg}^{-1} \mathrm{CP}, 320$ to $420 \mathrm{~g} \mathrm{~kg}^{-1}$ neutral detergent fiber (NDF), 210 to $300 \mathrm{~g} \mathrm{~kg}^{-1}$ acid detergent fiber (ADF), and 730 to $840 \mathrm{~g} \mathrm{~kg}^{-1}$ in vitro true digestibility at maturity.

Mothbean could be used to increase the supply and quality of forage in semiarid and arid regions (National Research Council, 1979). Individual plants have a vining and semi-trailing growth habit, which have the potential to cover large areas. As such, this low-growing legume has the potential to cover the soil surface to protect soil moisture, reduce soil temperatures, and decrease soil erosion (Bhardwaj and Hamama, 2016). Since it is a legume, mothbean can also improve soil fertility through $\mathrm{N}$ fixation (Vir and Singh, 2015).

Research on the use of mothbean as forage was initiated during the early 20th century and showed promising results in dry US environments (Conner, 1908; Kennedy and Madson, 1925). However, the crop was neglected afterward for unknown reasons. Based on its food and forage potentials, soil covering ability, and short life cycle, mothbean appears to be a candidate for improving not only livestock production systems when grown as a summer crop in rotation with winter wheat but also for increasing agro-ecosystem diversity in the SGP.

\section{COWPEA}

Cowpea [Vigna unguiculata (L.) Walp.] is an important herbaceous, warm-season legume that originated and was domesticated in Africa. Cowpea varieties exhibit different growing habits including tall and vine-like, short and bushy, or prostrate. Cowpea plants have leaves with three broad leaflets, white inflorescences, and curved pods (Sheahan, 2012). Most cowpea types possess an indeterminate stem and branch apices (Timko et al., 2007). It has a deep tap root, which has been measured at a depth of $2.9 \mathrm{~m}$ at flowering (Babalola, 1980). It is a valuable food legume and livestock feed in the semiarid tropics, including regions of Asia, southern Europe, Africa, Central and South America, and the southern United States (Timko and Singh, 2008).

Cowpea is a well-adapted and versatile crop, capable of good yields under high temperature and water deficits (Ehlers and Hall, 1997; Hall et al., 2002). It requires a minimum temperature of $18^{\circ} \mathrm{C}$ through all developmental stages (Timko and Singh, 2008; Badiane et al., 2014). Optimum growth occurs at mean daily air temperatures of $28^{\circ} \mathrm{C}$ (Craufurd et al., 1997). Cowpea is generally photo insensitive (Davis et al., 1991). It is drought tolerant and can produce a grain yield of about $1.1 \mathrm{Mg} \mathrm{ha}^{-1}$, with rainfall amounts as low as $180 \mathrm{~mm}$ during the growing season (Hall and Patel, 1985). However, it does not withstand flooded conditions over long periods (Clark, 2007). Cavalcante Junior et al. (2016) 
reported water requirements of cowpea ranging from 240 to 310 $\mathrm{mm}$ under semiarid conditions in Brazil. Cowpea can fix $\mathrm{N}$ and has performed well in sandy (80\%), low fertility soils with $<0.2 \%$ organic matter and low P (Sanginga et al., 2000). Cowpea is also shade tolerant, and capable of being intercropped with tall forage crops including sorghum [Sorghum bicolor (L.) Moench], maize, cotton (Gossypium hirsutum L.), and sugarcane (Saccharum officinarum L.; Singh et al., 2003).

Cowpea is an absolute multifunctional crop, since it serves as a highly nutritious food, a forage, and a green manure or cover crop. Cowpea grain has served as a dietary source of protein in areas with low-protein cereal and tuber-based diets. Cowpea seed contains $240 \mathrm{~g} \mathrm{~kg}^{-1}$ protein, $600 \mathrm{~g} \mathrm{~kg}^{-1}$ carbohydrates, $110 \mathrm{~g} \mathrm{~kg}^{-1}$ fiber, $13 \mathrm{~g} \mathrm{~kg}^{-1}$ fat, and considerable amounts of vitamins and minerals (USDA-ARS, 2016). It can also be employed as livestock feed (Singh et al., 2006).

Cowpea has the capacity to serve as fodder due to its high biomass yield and forage value. The common name cowpea even originated because of its use as hay for cattle in the United States and other parts of the world (Timko et al., 2007). Cowpea hay plays a critical role in feeding livestock during the dry season in West Africa (Tarawali et al., 1997). In a study on nutritive value of forage conducted in Iran (Dahmardeh et al., 2009), cowpea fodder was shown to have 156 to $196 \mathrm{~g} \mathrm{~kg}^{-1} \mathrm{CP}, 497$ to $545 \mathrm{~g}$ $\mathrm{kg}^{-1} \mathrm{NDF}$, and 293 to $322 \mathrm{~g} \mathrm{~kg}^{-1}$ ADF. It has a low risk of causing bloat in cattle, although bloat may occur on introducing hungry stock onto the crop (Mullen and Watson, 1999).

Generally, the short duration varieties (about 65-70 d) are grown for grain, whereas the long duration (110-130 d) varieties are used for forage. Some varieties with medium maturity rates (80-85 d) exist for a dual-purpose role. These varieties yield about $1.5 \mathrm{Mg} \mathrm{ha}^{-1}$ grain and $2.5 \mathrm{Mg} \mathrm{ha}^{-1}$ haulms, with a CP of 170 to $180 \mathrm{~g} \mathrm{~kg}^{-1}$ and dry matter digestibility of 640 to $710 \mathrm{~g} \mathrm{~kg}^{-1}$ (Singh et al., 2003). It is also an excellent cover crop candidate, being fast growing, having a long taproot, and immense vegetative spread (Sheahan, 2012). About 50 cowpea varieties are commercially grown in the United States in regions extending from the Great Lakes to Florida and from the Atlantic to Pacific coasts (Sheahan, 2012).

Cowpea is one of the few annual legumes besides soybean that has received some degree of research and use in the SGP. Forage cowpea in north-central Texas yielded 0.5 to $3.2 \mathrm{Mg} \mathrm{ha}^{-1}$ dry matter with CP concentrations ranging from 161 to $208 \mathrm{~g} \mathrm{~kg}^{-1}$ under dryland conditions; both amounts were greater than that of forage soybean (Muir, 2002). Rao and Northup (2009a) reported that cowpea had greater potential as a summer crop for forage or green cover than soybean during dry years in the SGP due to its shorter lifecycle, high $\mathrm{N}$ concentrations and forage digestibility. Depending on the management and seasonal circumstances, cowpea can be grazed 8 to $12 \mathrm{wk}$ after planting until the leafy portion has been eaten (Mullen and Watson, 1999). Cowpea appears to be another option for producers of the SGP wishing to grow a summer crop to enhance sustainability of rain-fed forage-livestock production systems. The genetic improvements in modern cultivars (Sheahan, 2012) indicates there is need for additional research on the values of cowpea as a summer forage in the SGP.

\section{MUNGBEAN}

Mungbean [Vigna radiata (L.) Wilczek.], also known as green gram, is an annual warm-season legume, with a highly branched and upright growth form, and trifoliate leaves. It has a welldeveloped taproot reaching to a depth of $1.0 \mathrm{~m}$ (Sangakkara et al., 2001). It is native to the northeastern Indo-Burma region, and is one of the major food legume crops of Asia (Bhardwaj and Hamama, 2016). Mungbean seeds provide high amounts of easily digestible protein for human consumption (Swaminathan et al., 2012). Mungbean grain contains $240 \mathrm{~g} \mathrm{~kg}^{-1}$ protein, $15 \mathrm{~g}$ $\mathrm{kg}^{-1}$ oil, and $50 \mathrm{~g} \mathrm{~kg}^{-1}$ sugars (Bhardwaj and Hamama, 2016). Whole seeds are commonly used to grow bean sprouts for salads or used in soup mixes in the United States.

Mungbean is adaptable and has been cultivated in different parts of the world including Southeast Asia, Africa, South America, North America, and Australia. It has a short life cycle, requiring 90 to 120 frost free days to achieve maturity (Ranawake et al., 2012). Mungbean is commonly grown with daily temperatures ranging from 20 to $40^{\circ} \mathrm{C}$; the minimum temperature requirement for emergence is $12^{\circ} \mathrm{C}$, and the range of optimum growth is 28 to $30^{\circ} \mathrm{C}$ (Fyfield and Gregory, 1989; Kaur et al., 2015). The total water requirement of mungbean ranges from 440 to $520 \mathrm{~mm}$ under irrigated conditions of northern India (Phogat et al., 1984; Pannu and Singh, 1993). However, mungbean can be grown successfully under lower moisture, rain-fed conditions (Ranawake et al., 2012). It requires guaranteed soil moisture via pre-sowing irrigation or adequate rainfall for better germination and stand establishment (Kumar and Sharma, 2009). Allahmoradi et al. (2011) reported vegetative growth of mungbean was more susceptible to drought stress than reproductive stages. However, Thomas et al. (2004) found mungbean was capable of recovering from drought stress during early development and compensating for yield losses later in the growing season.

The planting and production strategies for mungbean are similar to soybean, so producers in the SGP would not require specialized equipment for planting and grain harvest (Bhardwaj and Hamama, 2015) or different strategies for grazing management. Mungbean plants may have potential as cattle forage due to high digestibility $\left(825 \mathrm{~g} \mathrm{~kg}^{-1}\right)$ and $\mathrm{N}$ concentrations $\left(26 \mathrm{~g} \mathrm{~kg}^{-1}\right.$ ) (Rao and Northup, 2009a). Twidwell et al. (1992) reported CP concentrations of 150 to $230 \mathrm{~g} \mathrm{~kg}^{-1}$ in mungbean forage. Boe et al. (1991) reported forage yields of 3.75 to 7.25 $\mathrm{Mg} \mathrm{ha}^{-1}$ for cultivars of mungbean tested in the northern Great Plains. In comparison, Rao and Northup (2009a) obtained an average forage yield of about $3 \mathrm{Mg} \mathrm{ha}^{-1}$ in central Oklahoma in response to a range of different amounts of precipitation during growing seasons. Grazing of mungbean can start 6 wk after planting and two grazing periods are obtainable (FAO, 2012). Hay harvests should occur at initiation of flowering for optimum combination of quantity and quality of biomass (Heuzé et al., 2013).

Although mungbean has been grown in Oklahoma and Texas in the past, the current level of grain production is low. Most of the US demand for mungbean is met through import, with 15.8 and $16.4 \mathrm{Mg}$ of mungbean and urd bean (Vigna mungo L.) being imported in 2015 and 2016, respectively (USDA-ERS, $2017 \mathrm{~b}$ ). Such demand shows mungbean grain has US market value and could help increase farmer income in the SGP. This 
Table 2. Characteristics of annual legumes grown in different regions of the world with potential for the summer growing season of the Southern Great Plains.

\begin{tabular}{|c|c|c|c|c|c|c|c|c|c|c|c|}
\hline \multicolumn{7}{|c|}{ Growing conditions } & \multicolumn{5}{|c|}{ Forage quality } \\
\hline Crop & Native range & $\begin{array}{l}\text { Growing } \\
\text { climate }\end{array}$ & $\begin{array}{l}\text { Optimum } \\
\text { temp. }\end{array}$ & $\begin{array}{l}\text { Water } \\
\text { required }\end{array}$ & $\begin{array}{l}\text { Root } \\
\text { depth }\end{array}$ & $\begin{array}{c}\text { Growing } \\
\text { season }\end{array}$ & $\begin{array}{c}\text { Livestock } \\
\text { feed }\end{array}$ & $\mathrm{CP}$ & IVDDM & $\begin{array}{l}\text { Forage } \\
\text { yield }\end{array}$ & $\begin{array}{l}\text { Grain } \\
\text { yield }\end{array}$ \\
\hline & & & ${ }^{\circ} \mathrm{C}$ & $\mathrm{mm}$ & $\mathrm{m}$ & days & & $-\mathrm{g} \mathrm{k}$ & $\mathrm{kg}^{-1}$ & $\mathrm{Mg} \mathrm{H}$ & $\mathrm{a}^{-1}$ \\
\hline Soybean & China & Sub-humid & $25-30$ & $420-540$ & 1.5 & $100-120$ & Hay/graze & $150-190$ & $740-790$ & I.I-5.2 & $0.3-1.5$ \\
\hline Tepary bean & $\begin{array}{l}\text { NW Mexico and } \\
\text { SW United States }\end{array}$ & Arid & $25-35$ & NA & NA & $60-75$ & Hay/graze & 210 & $\mathrm{n} / \mathrm{a}$ & 4.4 & $0.8-1.6$ \\
\hline Mothbean & India & Arid & $24-32$ & $190-260$ & NA & $60-75$ & Hay/graze & $110-150$ & $730-840$ & $7.1-18.1$ & $0.1-1.0$ \\
\hline Cowpea & Africa & Semi-arid & 28 & $240-315$ & $0.8-2.8$ & $65-70$ & Hay/graze & $160-210$ & $640-710$ & $0.5-3.2$ & 1.5 \\
\hline Guar & Africa & Semi-arid & $25-35$ & 250 & NA & $90-120$ & Hay & $160-220$ & $610-710$ & $2.9-4.7$ & $1.1-1.8$ \\
\hline Mungbean & Indo-Burma & Sub-humid & $28-30$ & $440-520$ & 1.0 & $90-120$ & Hay/graze & $150-230$ & 825 & $3-7.5$ & 1.5 \\
\hline Pigeon pea & India & Semi-arid & $20-24$ & $200-240$ & 2.0 & $110-140$ & $\begin{array}{c}\text { Graze/seeds } \\
\text { as feed }\end{array}$ & 121 & 689 & $3-9$ & I.2-5.4 \\
\hline
\end{tabular}

value assumes the development of consumer demand (and marketing mechanisms) that exceeds its value as high quality forage for summer grazing by stocker cattle. Karamany (2006) investigated a dual-purpose approach for mungbean during summers in Egypt. They recorded $5 \mathrm{Mg} \mathrm{ha}^{-1}$ of high quality forage (172 $\left.\mathrm{g} \mathrm{kg}^{-1} \mathrm{CP}\right)$ at harvest of mungbean as hay at $65 \mathrm{~d}$ after sowing. These plots were also able to produce an average of $1.5 \mathrm{Mg} \mathrm{ha}^{-1}$ seed yield at the end of growing season. The short growing season of mungbean would result in grain harvest by late August in the SGP, which would help conserve soil moisture received in September and October for winter wheat (Rao and Northup. 2009b). Asim et al. (2006) also noted reduced weed, pathogen, and pest problems for subsequent wheat crops.

Mungbean plants are a potential crop choice to improve productivity of grazing systems, assist in soil moisture conservation, provide reliable economic benefits, and enhance soil fertility. Based on the long-term weather data of the six locations (shown in Fig. 2 and 3), mungbean seems to be a better fit for the eastern sections of the SGP due to greater water needs than other potential summer annual legume crops (Table 2).

\section{GUAR}

Guar [Cyamopsis tetragonoloba (L.) Taub.], also called cluster bean, is a drought tolerant, summer annual legume that is thought to have originated in Africa. It is mainly cultivated in semiarid zones of northwestern India, Sudan, and Pakistan. There has been some production and genetic development within the southern United States (Stafford, 1982; Reddy and Tammishetti, 2004). India is currently the largest producer ( $80 \%$ of world production) of guar in the world, followed by Pakistan (15\%), and the Middle East and African (5\%) countries (Gresta et al., 2013). Guar has a single upright main stem $(2-3 \mathrm{~m})$ with fine or basal branching stems, trifoliate leaves, $4-$ to $10-\mathrm{cm}$ long pods with 5 to 12 seeds per pod, and a deep taproot system enabling it to reach moisture below the surface layers of soil (Gresta et al., 2013).

Guar is a shorter-duration crop, requiring 90 to $120 \mathrm{~d}$ to reach maturity, which allows it to fit into different crop rotations (Rao and Northup, 2009a, 2013). However, guar is photosensitive, requiring long days for vegetative growth and short days for flowering and pod formation. Seed germination needs temperature within a range of 25 to $30^{\circ} \mathrm{C}$, and can grow at air temperatures of $35^{\circ} \mathrm{C}$ (Singh, 2014). Guar can grow in a wide range of soils, but performs best on fertile, medium textured soils with good drainage. Guar is a drought tolerant crop, delaying growth until moisture is available (Tripp et al., 1982). As such, guar can grow in areas receiving $\leq 250 \mathrm{~mm}$ of annual precipitation (Singla et al., 2016a). Therefore, the environmental conditions of regions where guar is grown in large quantity closely match conditions in the SGP.

Guar has great value in India due to its use to provide multiple products, including forage or feed for cattle, a nutritious vegetable (immature pods) for human consumption, a green manure for soil improvement, and a raw material for several different industries. The grain of guar is a rich source of protein, fiber, minerals ( $\mathrm{Ca}, \mathrm{Fe}$, and P), and ascorbic acid (Singh, 2014). Guar seeds have numerous industrial uses due to its binding capability and viscosity of the polysaccharide galactomannan (guar gum), which is obtained from the endosperm (Singla et al., 2016a). High-grade guar gum is utilized in food industries, whereas low-grade gum is used in the textile, paper, and mining industries. Recently, the demand and price of guar gum has increased globally due to its use in oil fracking (Gresta et al., 2013). Within the fracking industry, the largest consumption of guar gum in the world is by US companies, with most of the demand being met through importation (Singh, 2014; Singla et al., 2016b). Therefore, it is primarily grown as a seed crop in the United States. Singla et al. (2016b) reported grain yields of 1.1 to $1.8 \mathrm{Mg} \mathrm{ha}^{-1}$ for eight different varieties evaluated in Las Cruces, NM. Guar also can improve soils through its soil-binding roots and $\mathrm{N}$ fixation, which benefit subsequent crops (Wong and Parmar, 1997). Cotton yields were increased by $15 \%$ when grown in rotation with guar (Tripp et al., 1982).

Although guar has been cultivated mainly as a grain crop in the United States, it may also have forage potential, although information on the value of guar as either hay or grazed pasture is mixed. Guar hay was found to be palatable and digestible to livestock in India (Patnayak et al., 1979). In comparison, Rao and Northup (2013) suggested guar as potential forage for the SGP, and an annual alternative to high water-demanding legumes like alfalfa (Medicago sativa L.). Rao and Northup (2009a) reported 162 to $225 \mathrm{~g} \mathrm{~kg}^{-1} \mathrm{CP}$ and 606 to $712 \mathrm{~g} \mathrm{~kg}^{-1}$ IVDDM for forage produced by a grain cultivar Kinman in Oklahoma. Studies in the SGP also suggested that hay may be harvested during vegetative stages of growth, as $\mathrm{CP}$ and digestibility were continuously reduced with increasing levels of plant maturity (Rao and Northup, 2009a, 2013). Singla et al. (2016a) reported an average biomass yield of 2.9 to $3.8 \mathrm{Mg} \mathrm{ha}^{-1}$ near Las Cruces, NM. Rao and Northup (2013) reported a forage yield 
of 4.25 to $4.75 \mathrm{Mg} \mathrm{ha}^{-1}$ for three Indian-origin forage varieties grown in central Oklahoma.

Although the value of guar as a hay crop looks promising, there is limited information on its value as grazed pasture, and many reports are anecdotal. The surface of guar leaves is covered in fine hairs, which were thought to hinder grazing in India. However, there has been little research on the interaction between guar and grazing animals. Such information is important for defining the suitability of guar as forage or hay. Further research is also needed to ascertain more reliable forage-type cultivars, their performance and quality attributes, and best management practices for the variable environment of the SGP.

\section{PIGEON PEA}

Pigeon pea [Cajanus cajan (L.) Millsp.], also known as red gram, is a legume from the rainfed tropics and subtropics, which has a substantial shrub-type growth form (Singh and Oswalt, 1992). Pigeon pea originated and was domesticated in India. Plants of pigeon pea have erect, woody, pubescent stems of 1 to $4 \mathrm{~m}$ height, alternate trifoliate leaves, papallionaceous (butterfly-shaped) and yellow flowers organized in racemes, and pubescent pods that form at the axils of branches. Pigeon pea has a strong taproot, which can extend to a depth over $2 \mathrm{~m}$ (Singh and Oswalt, 1992).

There is a wide range of genetic materials for this legume, and cultivars with a broad range of length of growing seasons exist (Mallikarjuna et al., 2011). In its native range, there are perennial cultivars that can be grown for 3 to 5 yr. However, mostly annual cultivars are preferred for seed production in tropical and subtropical regions (Singh and Oswalt, 1992; Mallikarjuna et al., 2011). Short-duration cultivars have been developed that are capable of grain production in the southern United States (Phatak et al., 1993; Yu et al., 2014), and such materials were tested in the SGP (Rao et al., 2002, 2003). Pigeon pea contributed $6 \%$ of the total worldwide production of pulse crops in 2014 (FAO, 2017). Pigeon pea reaches maturity within a range of 120 to $210 \mathrm{~d}$ depending on the cultivar type, location, and sowing time. Rao et al. (2003) observed short-duration (110$140 \mathrm{~d}$ ) US varieties reached physiological maturity $118 \mathrm{~d}$ after planting in the SGP. Pigeon pea is a short-day plant and requires an optimum temperature between 20 and $24^{\circ} \mathrm{C}$ for development (McPherson et al., 1985; Carberry et al., 2001).

Pigeon pea can grow in soil types ranging from sand to heavy clay loams. The water requirements of pigeon pea in India ranged between 200 and $240 \mathrm{~mm}$ when grown during summer (Mahalakshmi et al., 2011). Limited accounts are available on water use by pigeon pea; however, it has remarkable drought tolerance due to its deep roots and ability to undergo osmotic adjustment in its leaves (Subbarao et al., 2000). Although pigeon pea is mainly grown under rainfed conditions, it is affected by intensity and timing of rainfall. Yu et al. (2014) in west-central Tennessee found $172 \%$ greater seed yield in a year receiving normal rainfall combined with drought during the early growing season compared with a year receiving heavy rainfall during early growing season and severe drought at flowering. Similar responses to different rainfall patterns occurred in central Oklahoma (Rao and Northup, 2009b). Pigeon pea was also noted to have higher water use efficiencies under dry conditions compared with wet growing conditions (Yu et al., 2014).
Pigeon pea has been used as a true multi-purpose crop in India and Africa, with the entire plant used to supply human and livestock feedstuffs, enhance soil fertility, and supply fuel for cooking fires (Singh and Oswalt, 1992). The raw mature seeds contain $193 \mathrm{~g} \mathrm{~kg}^{-1}$ protein, $627 \mathrm{~g} \mathrm{~kg}^{-1}$ carbohydrates, $64 \mathrm{~g} \mathrm{~kg}^{-1}$ fiber, $20 \mathrm{~g} \mathrm{~kg}^{-1}$ sugars and are a rich source of dietary minerals such as P, K, Mg, Ca, and Fe (Singh and Singh, 1992). The demand for pigeon pea seeds has increased during the last few years due to US immigration from countries where pigeon pea has been grown for grain or vegetable (immature pods).

Leaves and pods of pigeon pea are widely used as livestock forage due to high amounts of protein and palatability. Rao et al. (2003) reported average CP concentration and IVDDM of $212 \mathrm{~g} \mathrm{~kg}^{-1}$ and $758 \mathrm{~g} \mathrm{~kg}^{-1}$, respectively, for leaves, which was similar to alfalfa. However, the stems were low in CP $\left(56 \mathrm{~g} \mathrm{~kg}^{-1}\right)$ and digestibility $\left(420 \mathrm{~g} \mathrm{~kg}^{-1}\right)$, which lessens the overall forage value for the entire plant. Foster et al. (2009) reported pigeon pea raised in Florida contained $121 \mathrm{~g} \mathrm{~kg}^{-1} \mathrm{CP}, 695 \mathrm{~g} \mathrm{~kg}^{-1} \mathrm{NDF}$, and $689 \mathrm{~g} \mathrm{~kg}^{-1}$ IVDMD at final harvest. Rao and Northup (2012) noticed that cattle did not selectively graze primary and secondary stems of pigeon pea during a grazing trial, likely due to high lignin content and low digestibility. A later trial in Oklahoma recorded higher amounts of tannins in the stems of pigeon pea than in leaves (B. Northup, unpublished data, 2010). The by-products of split seeds for human consumption can provide a low-cost source of protein for animals compared with other sources of feed supplements such as fish and bone meal (Phatak et al., 1993).

The value of pigeon pea grown for grain and forage has been researched in Tennessee, Florida, Virginia, and Oklahoma. Results showed some degree of adaptation of pigeon pea in these different regions. Low water requirements and high drought tolerance indicates that pigeon pea would fit as a multi-purpose summer crop for the SGP. Early maturing varieties have the potential to provide grain and sufficient herbage of moderate nutritive value for grazing. Rao and Northup (2012) observed animal gains of $140 \mathrm{~kg} \mathrm{ha}^{-1}$ and average daily gain of $1.0 \mathrm{~kg}$ during late August through early September grazing bouts, compared with 0.5 to $0.75 \mathrm{~kg} \mathrm{~d}^{-1}$ gain for warm-season grasses. However, there is need to develop new cultivars with greater leaf/stem ratios and finer stems to provide greater amounts of high nutritive value forage and allow longer grazing periods. In addition, systems-level water, nutrient, and economic budgets need to be evaluated so producers can make informed decisions regarding the use of wheat-pigeon pea rotations in the SGP.

\section{CONCLUSION}

The short list of discussed pulses represents a small segment of the entire population of under-utilized or neglected legumes that exist worldwide. In some cases, their value as forage could exceed the most common pulse (soybean) used in the SGP. Both tepary bean and mothbean were known for their remarkable drought tolerance in the early 20th century, but were neglected afterward. They are likely to be valuable in rainfed systems in the SGP, due to their excellent soil-covering ability and heat and drought tolerance. There is a need to evaluate the capacity of cultivars of these two species from different regions of the world to examine their adaptability to the varied growing conditions that exist in the SGP. 
Cowpea has been a commonly used summer cover crop by producers in the drier regions of Oklahoma and Texas where other legumes rarely succeed. Mungbean has also shown high forage yields and nutritive value, but is less drought-tolerant than cowpea. Thus, mungbean may fit well in eastern parts of the SGP, which receive more precipitation during summer. The US grain market for both cowpea and mungbean crops is expanding due to increasing Asian and African populations and shifts in dietary preferences. Therefore, their grain production may also provide some potential for producers to generate improved cost-benefit ratios.

Seed of guar is also in high demand due to their industrial uses, but the nutritive value of guar forage declines with maturity. There would be tradeoffs between the values of grain crops and forage value of guar if producers chose harvesting hay at maturity. Studies involving overall economic analysis of animal gain and grain production can bring more insight on value of guar in the SGP. Pigeon pea has shown its ability to produce grain and forage with moderate nutritive value that supports animal gain compared with traditional warm-season grasses. However, developing new cultivars with greater leaf/stem ratios can further improve nutritive value and allow lengthier grazing periods.

In general, all of the discussed crops show potential of use as components of different strategies to increase precipitation use efficiency, minimize soil erosion, meet $\mathrm{N}$ requirements for following crops, and build organic matter and soil structure. Examination of management practices to define best practices for growing these novel crops and their comparison to more commonly used pulses are required. Further, systems-level water, nutrient, and economic impacts of growing these crops in rotation with winter wheat need to be evaluated for optimal enhancement and improved overall effectiveness of forage-stocker systems.

\section{REFERENCES}

Aiken, R.M., D.M. O’Brien, B.L. Olson, and L. Murray. 2013. Replacing fallow with continuous cropping reduced crop water productivity of semiarid wheat. Agron. J. 105:199-207. doi:10.2134/ agronj2012.0165

Ajayi, F.T., S.R. Akande, A.A. Adegbite, and B. Idowu. 2009. Assessment of seven under-utilized grain legume foliage as feed resources for ruminants. Livest. Res. Rural Dev. 21(9):149. http://www.lrrd.org/ lrrd21/9/ajay21149.htm (accessed 22 Aug. 2018).

Allahmoradi, P., M. Ghobadi, S. Taherabadi, and S. Taherabadi. 2011. Physiological aspects of mungbean (Vigna radiata L.) in response to drought stress. International Conference on Food Engineering and Biotechnology, IPCBEE, vol. 9. IACSIT Press, Singapore, p. 272-275.

Asim, M., M. Aslam, N.I. Hashmi, and N.S. Kisana. 2006. Mungbean (Vigna radiata) in wheat based cropping system: An option for resource conservation under rainfed ecosystem. Pak. J. Bot. $37: 1197-1204$

Babalola, O. 1980. Water relations of three cowpea cultivars (Vigna unguiculata L.). Plant Soil 56:59-69. doi:10.1007/BF02197953

Badiane, F.A., M. Diouf, and D. Diouf. 2014. Cowpea In: M. Singh, I.S. Bisht, and M. Dutta, editors, Broadening the genetic base of grain legumes. Springer, India. p. 95-114.

Baath, G.S., B.K. Northup, P.H. Gowda, K.E. Turner, and A.C. Rocateli. 2018. Mothbean: A potential summer crop for the Southern Great Plains. Am. J. Plant Sci. 9:1391-1402. doi:10.4236/ajps.2018.97101
Beck, P.A., D.S. Hubbell, T.W. Hess, K.D. Wilson, and J.A. Williamson. 2017. Effect of a forage-type soybean cover crop on wheat forage production and animal performance in a continuous wheat pasture system. Prof. Anim. Sci. 33:659-667. doi:10.15232/pas.2017-01660

Bhardwaj, H.L. 2013. Preliminary evaluation of tepary bean (Phaseolus acutifolius A. gray) as a forage crop. J. Agric. Sci. 5:160-166.

Bhardwaj, H.L., and A.A. Hamama. 2004. Protein and mineral composition of tepary bean seed. HortScience 39:1363-1365.

Bhardwaj, H.L., and A.A. Hamama. 2005. Oil and fatty acid composition of tepary bean seed. HortScience 40:1436-1438.

Bhardwaj, H.L., and A.A. Hamama. 2015. Cultivar, planting date, and row spacing effects on mungbean performance in Virginia. HortScience 50:1309-1311.

Bhardwaj, H.L., and A.A. Hamama. 2016. Cultivar, planting date, and row spacing effects on mungbean seed composition. J. Agric. Sci. $8: 26-32$.

Bhardwaj, H.L., M. Rangappa, and A.A. Hamama. 2002. Planting date and genotype effects on tepary bean productivity. HortScience 37:317-318

Boe, A., E.K. Twidwell, and K.D. Rephart. 1991. Growth and forage yield of cowpea and mungbean in the Northern Great Plains. Can. J. Plant Sci. 71:709-715. doi:10.4141/cjps91-104

Butler, T.J., and J.P. Muir. 2012. Perspective on forage legume systems for the tallgrass and mixed-grass prairies of the Southern Great Plains of Texas and Oklahoma. Crop Sci. 52:1971-1979. doi:10.2135/ cropsci2011.12.0674

Carberry, P.S., R. Ranganathan, L.J. Reddy, Y.S. Chauhan, and M.J. Robertson. 2001. Predicting growth and development of pigeonpea: Flowering response to photoperiod. Field Crops Res. 69:151-162. doi:10.1016/S0378-4290(00)00138-6

Cavalcante Junior, E.G., J.F.D. Medeiros, J. Espínola Sobrinho, V.B. Figueirêdo, J.P. da Costa, and W.D.O. Santos. 2016. Development and water requirements of cowpea under climate change conditions in the Brazilian semi-arid region. Rev. Bras. Eng. Agric. Ambient. 20:783-788. doi:10.1590/1807-1929/agriambi.v20n9p783-788

Chivenge, P., T. Mabhaudhi, A.T. Modi, and P. Mafongoya. 2015. The potential role of neglected and underutilised crop species as future crops under water scarce conditions in Sub-Saharan Africa. Int. J. Environ. Res. Public Health 12:5685-5711. doi:10.3390/ ijerph120605685

Ciampitti, I.A., and F. Salvagiotti. 2018. New insights into soybean biological nitrogen fixation. Agron. J. 110:1185-1196. doi:10.2134/ agronj2017.06.0348

Clark, A., editor. 2007. Cowpeas: Vigna unguiculata. In: Managing cover crops profitably. 3rd ed. Sustainable Agriculture Research and Education, College Park, MD. p. 125-129. http://www.sare.org/ Learning-Center/Books/Managing-Cover-Crops-Profitably-3rdEdition/Text-Version/Legume-Cover-Crops/Cowpeas (accessed 22 Aug. 2018).

Coleman, S.W., and T. Forbes. 1998. Herbage characteristics and performance of steers grazing old world bluestem. J. Range Manage. 51:399-407. doi:10.2307/4003324

Coleman, S.W., S.C. Rao, J.D. Volesky, and W.A. Phillips. 2010. Growth and nutritive value of perennial C3 grasses in the southern Great Plains. Crop Sci. 50:1070-1078. doi:10.2135/cropsci2009.04.0177

Conner, A.B. 1908. Forage crops in northwest Texas. Agric. Exp. Stn. Bull. 103. Texas Agric. Exp. Stn., College Station, TX.

Conservation Technology Information Center. 2004. National survey of conservation tillage practices. CTIC, West Lafayette, IN.

Craufurd, P.Q., R.J. Summerfield, R.H. Ell, and E.H. Roberts. 1997. Photoperiod, temperature and the growth and development of cowpea (Vigna unguiculata). In: B.B. Singh, D.R. Mohan Raj, K.E. Dashiell, and L.E.N. Jackai, editors, Advances in cowpea research. Copublication Intl. Inst. Tropical Agric. (IITA) and Japan Intl. Res. Center Agric. Sci. (JIRCAS), Sayce, Devon. p. 75-86. 
Dahmardeh, M., A. Ghanbari, B. Syasar, and M. Ramrodi. 2009. Intercropping maize (Zea mays L.) and cow pea (Vigna unguiculata L.) as a whole-crop forage: Effects of planting ratio and harvest time on forage yield and quality. J. Food Agric. Environ. 7:505-509.

Davis, D.W., E.A. Oelke, E.S. Oplinger, J.D. Doll, C.V. Hanson, and D.H. Putnam. 1991. Cowpea. Alternative field crops manual. Univ. of Wisconsin Coop. Ext Service, Madison, WI.

Decker, J.E., F.M. Epplin, D.L. Morley, and T.F. Peeper. 2009. Economics of five wheat production systems with no-till and conventional tillage. Agron. J. 101:364-372. doi:10.2134/agronj2008.0159

Edwards, J.T., B.F. Carver, G.W. Horn, and M.E. Payton. 2011. Impact of dual-purpose management on wheat grain yield. Crop Sci. 51:21812185. doi:10.2135/cropsci2011.01.0043

Ehlers, J.D., and A.E. Hall. 1997. Cowpea (Vigna unguiculata L. Walp.). Field Crops Res. 53:187-204. doi:10.1016/S0378-4290(97)00031-2

Farahani, H.J., G.A. Peterson, and D.G. Westfall. 1998. Dryland cropping intensification: A fundamental solution to efficient use of precipitations. Adv. Agron. 64:197-223. doi:10.1016/ S0065-2113(08)60505-2

FAO. 2012. Grassland index. A searchable catalogue of grass and forage legumes. FAO, Rome.

FAO. 2017. Food and Agriculture Organization statistics database. FAO, Rome. http://www.fao.org/faostat/en/\#data/QC (accessed 5 Sept. 2018).

Fieser, B.G., G.W. Horn, J.T. Edwards, and E.G. Krenzer, Jr. 2006. Timing of grazing termination in dual-purpose winter wheat enterprises. Prof. Anim. Sci. 22:210-216.

Foster, J.L., A.T. Adesogan, J.N. Carter, L.E. Sollenberger, A.R. Blount, R.O. Myer, S.C. Phatak, and M.K. Maddox. 2009. Annual legumes for forage systems in the United States Gulf Coast region. Agron. J. 101:415-421. doi:10.2134/agronj2008.0083x

Friedman, M., and D.L. Brandon. 2001. Nutritional and health benefits of soy proteins. J. Agric. Food Chem. 49:1069-1086. doi:10.1021/ jf0009246

Fyfield, T.P., and P.J. Gregory. 1989. Effects of temperature and water potential on germination, radicle elongation and emergence of mungbean. J. Exp. Bot. 40:667-674. doi:10.1093/jxb/40.6.667

Garcia-Gasca, T., L.A. Salazar-Olivo, E. Mendiola-Olaya, and A. BlancoLabra. 2002. The effects of a protease inhibitor fraction from tepary bean (Phaseolus acutifolius) on in vitro cell proliferation and cell adhesion of transformed cells. Toxicol. In Vitro 16:229-233. doi:10.1016/S0887-2333(02)00006-1

Guo, J., Y. Wang, C. Song, J. Zhou, L. Qiu, H. Huang, and Y. Wang. 2010. A single origin and moderate bottleneck during domestication of soybean (Glycine max): Implications from microsatellites and nucleotide sequences. Ann. Bot. (London) 106:505-514. doi:10.1093/ aob/mcq125

Gresta, F., O. Sortino, C. Santonoceto, L. Issi, C. Formantici, and Y.M. Galante. 2013. Effects of sowing times on seed yield, protein and galactomannans content of four varieties of guar (Cyamopsis tetragonoloba L.) in a Mediterranean environment. Ind. Crops Prod. 41:46-52. doi:10.1016/j.indcrop.2012.04.007

Hall, A.E., and P.N. Patel. 1985. Breeding for resistance to drought and heat. In: S.R. Singh and K.O. Rachie, editors, Cowpea research, production, and utilization. John Wiley \& Sons, New York. p. 137-151.

Hall, A.E., A.M. Ismai, J.D. Ehler, K.O. Marfo, N. Cisse, S. Thiaw, and T.J. Close. 2002. Breeding cowpea for tolerance to temperature extremes and adaptation to drought. In: C.A. Ratoku, S.A. Tarawali, B.B. Singh, P.M. Kormawa, and M. Tamo, editors, Challenges and opportunities for enhancing sustainable cowpea production. Int. Inst. Tropic. Agric., Ibadan, Nigeria. p. 14-21.

Heuzé, V., G. Tran, D. Bastianelli, and F. Lebas. 2013. Mung bean (Vigna radiata). Feedipedia, a programme by INRA, CIRAD, AFZ and FAO. http://www.feedipedia.org/node/235 (accessed May 2017).
Hintz, R.W., K.A. Albrecht, and E.S. Oplinger. 1992. Yield and quality of soybean forage as affected by cultivar and management practices. Agron. J. 84:795-798. doi:10.2134/agronj1992.000219620084000 $50007 \mathrm{x}$

Hossain, I., F.M. Epplin, G.W. Horn, and E.R. Krenzer, Jr. 2004. Wheat production and management practices used by Oklahoma grain and livestock producers. Oklahoma Agric. Exp. Stn. B-818. Oklahoma State University, Stillwater.

Jiri, O., and P. Mafongoya. 2016. Tepary bean: A climate smart crop for food and nutritional security. J. Nutr. Food Sci. 6:1-7.

Kannan, N., E. Osei, O. Gallego, and A. Saleh. 2017. Estimation of green water footprint of animal feed for beef cattle production in Southern Great Plains. Water Resour. Ind. 17:11-18. doi:10.1016/j. wri.2016.12.002

Karamany, E.L. 2006. Double purpose (forage and seed) of mung bean production. 1. Effect of plant density and forage cutting date on forage and seed yields of mung bean (Vigna radiata (L.) Wilczck). Res. J. Agric. Biol. Sci. 2:162-165.

Kaur, R., T.S. Bains, H. Bindumadhava, and H. Nayyar. 2015. Responses of mungbean (Vigna radiata L.) genotypes to heat stress: Effects on reproductive biology, leaf function and yield traits. Sci. Hortic. (Amsterdam) 197:527-541. doi:10.1016/j.scienta.2015.10.015

Kelley, K.W., and D.W. Sweeney. 2010. Long-term crop rotation and tillage affects wheat and double-crop soybean and selected soil properties. Crop Manage. 9. doi:10.1094/CM-2010-0707-01-RS

Kennedy, P.B., and B.A. Madson. 1925. The mat bean: Phaseolus aconitifolius. Agric. Exp. Stn., University of California, Berkeley, CA.

Knott, C.A., E.M. Swiggart, J.H. Grove, and E.R. Haramoto. 2018. Double-crop soybean germination, seedling growth, and seed yield differences when preceded by different winter annuals. Agron. J. 110:1430-1438. doi:10.2134/agronj2017.11.0639

Kumar, A., and K.D. Sharma. 2009. Physiological responses and dry matter partitioning of summer mungbean (Vigna radiata L.) genotypes subjected to drought conditions. J. Agron. Crop Sci. 195:270-277. doi:10.1111/j.1439-037X.2009.00373.x

Kumar, R.A., and M. Singh. 1984. Tannins: Their adverse role in the ruminant nutrition.J. Agric. Food Chem. 32:447-453. doi:10.1021/ jf00123a006

Kumar, D., and A.B. Rodge. 2012. Status, scope and strategies of arid legumes research in India-A review. J. Food Legumes 25:255-272.

LaCasha, P.A., H.A. Brady, V.G. Allen, C.R. Richardson, and K.R. Pond. 1999. Voluntary intake, digestibility, and subsequent selection of matua bromegrass, coastal bermudagrass, and alfalfa hays by yearling horses. J. Anim. Sci. 77:2766-2773. doi:10.2527/1999.77102766x

Lee, S.H., M.A. Bailey, M.A.R. Mian, T.E. Carter, D.A. Ashley, R.S. Hussey, W.A. Parrott, and H.R. Boerma. 1996. Molecular markers associated with soybean plant height, lodging, and maturity across locations. Crop Sci. 36:728-735. doi:10.2135/cropsci1996.0011183 X003600030035x

Lyon, D.J., D.C. Nielsen, D.G. Felter, and P.A. Burgener. 2007. Choice of summer fallow replacement crops impacts subsequent winter wheat. Agron. J. 99:578-584. doi:10.2134/agronj2006.0287

MacKown, C.T., J.J Heitholt, and S.C. Rao. 2007. Agronomic feasibility of a continuous double crop of winter wheat and soybean forage in the southern Great Plains. Crop Sci. 47:1652-1660. doi:10.2135/ cropsci2006.10.0683

Mahalakshmi, K., K.A. Kumar, M.D. Reddy, and M.U. Devi. 2011. Response of rabi pigeon pea [Cajanus cajan (L.)] to different levels of drip irrigation. J. Res. ANGRAU. 39:101-103.

Mallikarjuna, N., K.B. Saxena, and D.R. Jadhav. 2011. Cajanus. In: K. Chittaranjan, editor, Wild crop relatives: Genomic and breeding resources- legume crops and forages. Springer-Verlag, Berlin, Heidelberg. doi:10.1007/978-3-642-14387-8_2 
Manga, V.K., A.K. Juktani, and R.K. Bhatt. 2015. Adaptation and selection of crop varieties for hot arid climate of Rajasthan. Indian J. Plant Sci. 4:1-9.

Markhart, A.H. 1985. Comparative water relations of Phaseolus vulgaris L. and Phaseolus acutifolius Gray. Plant Physiol. 77:113-117. doi:10.1104/pp.77.1.113

McPherson, H.G., I.J. Warrington, and H.L. Turnbull. 1985. The effects of temperature and daylength on the rate of development of pigeonpea. Ann. Bot. (London) 56:597-611. doi:10.1093/oxfordjournals. aob.a087050

Miklas, P.N., J.C. Rosas, J.S. Beaver, L. Telek, and G.F. Freytag. 1994. Field performance of select tepary bean germplasm in the tropics. Crop Sci. 34:1639-1644. doi:10.2135/cropsci1994.0011183X0034 00060040x

Miklas, P.N., and J. Santiago. 1996. Reaction of select tepary bean to bean golden mosaic virus. HortScience 31:430-432.

Molosiwa, O.O., S.B. Kgokong, B. Makwala, C. Gwafila, and M.G. Ramokapane. 2014. Genetic diversity in tepary bean (Phaseolus acutifolius) landraces grown in Botswana. J. Plant Breed. Crop Sci. 6:194-199. doi:10.5897/JPBCS2014.0458

Muir, J.P. 2002. Hand-plucked forage yield and quality and seed production from annual and short-lived perennial warm-season legumes fertilized with composted manure. Crop Sci. 42:897-904. doi:10.2135/cropsci2002.0897

Mullen, C., and R.W. Watson. 1999. Summer legume forage crops: Cowpeas, lablab, soybeans. AgFact. 4. NSW Agriculture. Orange, NSW, Australia.

Narain, P., R.S. Singh, and D. Kumar. 2001. Droughts and dew bean productivity in northwestern arid Rajasthan, India. In: Drought Network News (1994-2001) 28. http://digitalcommons.unl.edu/ droughtnetnews/28 (accessed 23 Mar. 2017).

National Research Council. 1979. Tropical legumes: Resources for the future. Natl. Acad. Sci., Washington, DC.

Nielsen, D.C. 2011. Forage soybean yield and quality response to water use. Field Crops Res. 124:400-407. doi:10.1016/j.fcr.2011.07.007

Neel, J.P.S., J.P. Fontenot, W.M. Chapham, S.K. Duckett, E.E.D. Felton, G. Scaglia, and W.B. Bryan. 2007. Effects of winter stocker growth rate and finishing system on: I. Animal performance and carcass characteristics. J. Anim. Sci. 85:2012-2018. doi:10.2527/ jas.2006-735

Northup, B., W. Phillips, and H. Mayeux. 2007. Improving productivity of winter wheat-stocker calf enterprises by including perennial coolseason grasses. In: Proc. 3rd Natl. Conf. Grazing Lands, St. Louis, MO. 10-13 Dec. p. 257-260.

Northup, B.K., and S.C. Rao. 2015. Green manure and forage potential of lablab in the US southern Plains. Agron. J. 107:1113-1118. doi:10.2134/agronj14.0455

Northup, B.K., and S.C. Rao. 2016. Effects of legume green manures on non-grain biomass of continuous wheat systems. Agron. J. 108:101108. doi:10.2134/agronj15.0031

NRC. 1996. Nutrient requirements of beef cattle, 7th ed. National Research Council, Washington, DC.

Ordóñez, R.A., M.J. Castellano, J.L. Hatfield, J.M. Helmers, M.A. Licht, M.Liebman, R. Dietzel, R. Martinez-Feria,J. Iqbal, L.A. Puntel, S.C. Córdova, K. Togliatti, E.E. Wright, and S.V. Archontoulis. 2018. Maize and soybean root front velocity and maximum depth in Iowa, USA. Field Crops Res. 215:122-131. doi:10.1016/j.fcr.2017.09.003

Pannu, R.K., and D.P. Singh. 1993. Effect of irrigation on water use, water-use efficiency, growth and yield of mungbean. Field Crops Res. 31:87-100. doi:10.1016/0378-4290(93)90052-O

Patnayak, B.C., M. Mohan, D.R. Bhatia, and A. Hajra. 1979. Nutritional value of cowpea, moth (dewgram) and clusterbean fodders fed as hay to sheep. Indian J. Anim. Sci. 49:746-748.
Patrignani, A., R.P. Lollato, T.E. Ochsner, C.B. Godsey, and J.T. Edwards. 2014. Yield gap and production gap of rainfed winter wheat in the southern Great Plains. Agron. J. 106:1329-1339. doi:10.2134/ agronj14.0011

Payero, J.O., S.R. Melvin, and S. Irmak. 2005. Response of soybean to deficit irrigation in the semi-arid environment of west-central Nebraska. Trans. ASAE 48:2189-2203. doi:10.13031/2013.20105

Peel, D.S. 2003. Beef cattle growing and backgrounding programs. Vet. Clin. North Am. Food Anim. Prac. 19:365-385.

Phatak, S.C., R.G. Nadimpalli, S.C. Tiwari, and H.L. Bhardwaj. 1993. Pigeonpeas: Potential new crop for the southeastern United States. In: J. Janick and J.E. Simon, editors, New crops. John Wiley \& Sons, New York. p. 597-599.

Phillips, W.A., and S.W. Coleman. 1995. Productivity and economic return of three warm season grass stocker systems for the Southern Great Plains. J. Prod. Agric. 8:334-339. doi:10.2134/jpa1995.0334

Phillips, W., B. Northup, and B. Venuto. 2009. Dry matter intake and digestion of perennial and annual cool-season grasses by sheep. Prof. Anim. Sci. 25:610-618.

Phogat, B.S., D.P. Singh, and P. Singh. 1984. Responses of cowpea (Vigna unguiculata (L.) Walp.) and mung bean (Vigna radiata (L.) Wilczek) to irrigation. Irrig. Sci. 5:47-60. doi:10.1007/BF00275037

Porch, T.G., J.S. Beaver, and M.A. Brick. 2013. Registration of tepary germplasm with multiple-stress tolerance, TARS-Tep 22 and TARSTep 32. J. Plant Reg. 7:358-364. doi:10.3198/jpr2012.10.0047crg

Pratt, R.C., N.K. Singh, R.E. Shade, L.L. Murdock, and R.A. Bressan. 1990. Isolation and partial characterization of a seed lectin from tepary bean that delays bruchid beetle development. Plant Physiol. 93:1453-1459. doi:10.1104/pp.93.4.1453

Pratt, R.C. 1983. Gene transfer between tepary and common beans. Desert Plants 5:57-63.

Price, M.L., A.E. Haggerman, and L.G. Butler. 1980. Tannin content of cowpeas, chick peas, pigeon peas, and mung beans. J. Agric. Food Chem. 28:459-461. doi:10.1021/jf60228a047

Probst, A.H., and R.W.Judd. 1973. Origin, U.S. history, development, and world distribution. In: B.E. Caldwell, editor, Soybeans: Improvement, production, and uses. Agron. Monogr. 16. ASA, CSSA, and SSSA, Madison, WI. p. 1-15.

Rainey, K.M., and P.D. Griffiths. 2005. Evaluation of Phaseolus acutifolius A. Gray plant introductions under high temperatures in a controlled environment. Genet. Resour. Crop Evol. 52:117-120. doi:10.1007/ s10722-004-1811-2

Ranawake, A.L., N. Dahanayaka, U.G.S. Amarasingha, W.D.R.J. Rodrigo, and U.T.D. Rodrigo. 2012. Effect of water stress on growth and yield of mung bean (Vigna radiata L). Tropic. Agric. Res. Ext. $14: 4$.

Rao, A.S., and S. Poonia. 2011. Climate change impact on crop water requirements in arid Rajasthan. J. Agrometerol. 13:17-24.

Rao, S.C., and B.K. Northup. 2009a. Capabilities of four novel warmseason legumes in the southern Great Plains: Biomass and forage quality. Crop Sci. 49:1096-1102. doi:10.2135/cropsci2008.08.0499

Rao, S.C., and B.K. Northup. 2009b. Water use by five warm-season legumes in the southern Great Plains. Crop Sci. 49:2317-2324. doi: $10.2135 /$ cropsci2009.03.0134

Rao, S.C., and B.K. Northup. 2011a. Grass pea (Lathyrus sativus L.) as a pre-plant nitrogen source for continuous conventionally tilled winter wheat. Crop Sci. 51:1325-1333. doi:10.2135/cropsci2010.08.0455

Rao, S.C., and B.K. Northup. 2011b. Grass pea as a nitrogen source for continuous no-till winter wheat. Crop Sci. 51:1824-1831. doi:10.2135/ cropsci2010.09.0513

Rao, S.C., and B.K. Northup. 2012. Pigeon pea potential for summer grazing in the Southern Great Plains. Agron. J. 104:199-203. doi:10.2134/agronj2011.0260 
Rao, S.C., and B.K. Northup. 2013. Biomass production and quality of indian-origin forage guar in Southern Great Plains. Agron. J. 105:945-950. doi:10.2134/agronj2012.0378

Rao, S.C., H.S. Mayeux, and B.K. Northup. 2005. Performance of forage soybean in the Southern Great Plains. Crop Sci. 45:1973-1977. doi:10.2135/cropsci2004.0598

Rao, S.C., S.W. Coleman, and H.S. Mayeux. 2002. Forage production and nutritive value of selected pigeon pea ecotypes in the Southern Great Plains. Crop Sci. 42:1259-1263. doi:10.2135/cropsci2002.1259

Rao, S.C., and B.K. Northup. 2008. Forage and grain sorghum effects on soil water content and use efficiency. Crop Sci. 48:789-793. doi:10.2135/cropsci2007.08.0423

Rao, S.C., W.A. Phillips, H.S. Mayeux, and S.C. Phatak. 2003. Potential grain and forage production of early maturing pigeon pea in the Southern Great Plains. Crop Sci. 43:2212-2217. doi:10.2135/ cropsci2003.2212

Reddy, T.T., and S. Tammishetti. 2004. Free radical degradation of guar gum. Polym. Degrad. Stab. 86:455-459. doi:10.1016/j. polymdegradstab.2004.05.017

Redmon, L., G.W. Horn, E.G. Krenzer, and D.J. Bernardo. 1995. A review of livestock grazing and wheat grain yield: Boom or bust? Agron. J. 87:137-147. doi:10.2134/agronj1995.00021962008700020001x

Salem, M.A., V.G. Kakani, S. Koti, and K.R. Reddy. 2007. Pollen-based screening of soybean genotypes for high temperatures. Crop Sci. 47:219-231. doi:10.2135/cropsci2006.07.0443

Sangakkara, U.R., M. Frehner, and J. Nösberger. 2001. Influence of soil moisture and fertilizer potassium on the vegetative growth of mungbean (Vigna radiata L. Wilczek) and cowpea (Vigna unguiculata L. Walp). J. Agron. Crop Sci. 186:73-81. doi:10.1046/j.1439-037X.2001.00433.x

Sanginga, N., O. Lyasse, and B.B. Singh. 2000. Phosphorus use efficiency and nitrogen balance of cowpea breeding lines in a low $\mathrm{P}$ soil of the derived savanna zone in West Africa. Plant Soil 220:119-128. doi:10.1023/A:1004785720047

Savage, D.A., and D.F. Costello. 1948. The southern Great Plains: The region and its needs. Yearbook of agriculture. USDA, Washington, DC.p. 503-506.

Schneider, J.M., and J.D. Garbrecht. 2003. A measure of the usefulness of seasonal precipitation forecasts for agricultural applications. Trans. ASAE 46:257-267. doi:10.13031/2013.12976

Scully, B., and J.G. Waines. 1987. Germination and emergence response of common and tepary beans to controlled temperature. Agron. J. 79:287-291. doi:10.2134/agronj1987.00021962007900020022x

Scully, B., and J.G. Waines. 1988. Ontogeny and yield response of common and tepary beans to temperature. Agron. J. 80:921-925. doi:10.2134/agronj1988.00021962008000060016x

Setiyono, T.D., A. Weiss, J. Specht, A.M. Bastidas, K.G. Cassman, and A. Dobermann. 2007. Understanding and modeling the effect of temperature and daylength on soybean phenology under highyield conditions. Field Crops Res. 100:257-271. doi:10.1016/j. fcr.2006.07.011

Sheaffer, C.C., J.H. Orf, T.E. Devine, and J.G. Jewett. 2001. Yield and quality of forage soybean. Agron. J. 93:99-106. doi:10.2134/ agronj2001.93199x

Sheahan, C.M. 2012. Plant guide for cowpea (Vigna unguiculata). USDANRCS, Cape May Plant Materials Center, Cape May, NJ.

Shisanya, C.A. 2002. Improvement of drought adapted tepary bean (Phaseolus acutifolius A. Gray var. latifolius) yield through biological nitrogen fixation in semi-arid SE-Kenya. Eur. J. Agron. 16:13-24. doi:10.1016/S1161-0301(01)00117-4

Siddhuraju, P., K. Vijayakumari, and K. Janardhanan. 1994. Chemical analysis and nutritional assessment of the less known pulses, Vigna aconitifolia (Jacq.) Marechal and Vigna vexillata (L.) A. Rich. Plant Foods Hum. Nutr. 45:103-111. doi:10.1007/BF01088467
Singh, F., and D.L. Oswalt. 1992. Pigeonpea botany and production practices. Skill Development Ser. 9. ICRISAT, Pattancheru, Andhra Pradesh, India.

Singh, U., and B. Singh. 1992. Tropical grain legumes as important human foods. Econ. Bot. 46:310-321. doi:10.1007/BF02866630

Singh, S.P., and C.G. Munoz. 1999. Resistance to common bacterial blight among Phaseolus species and common bean improvement. Crop Sci. 39:80-89. doi:10.2135/cropsci1999.0011183X003900010013x

Singh, R.S., A.S. Rao, N.L. Joshi, and Y.S. Ramakrishna. 2000. Evapotranspiration rates and water utilization of moth bean under two soil moisture conditions. Ann. Arid Zone 39:21-28.

Singh, B.B., H.A. Ajeigbe, S.A. Tarawali, S. Fernandez-Rivera, and M. Abubakar. 2003. Improving the production and utilization of cowpea as food and fodder. Field Crops Res. 84:169-177. doi:10.1016/ S0378-4290(03)00148-5

Singh, S., S.S. Kundu, A.S. Negi, and P.N. Singh. 2006. Cowpea (Vigna unguiculata) legume grains as protein source in the ration of growing sheep. Small Rumin. Res. 64:247-254. doi:10.1016/j. smallrumres.2005.04.022

Singh, S.K. 2014. An analysis of performance of guar crop in India. GAIN Rep. IN4035.USDA, New Delhi, India. https://bit.ly/2LH69wT (accessed 30 Aug. 2018).

Singla, S., K. Grover, S.V. Angadi, S.H. Begna, B. Schutte, and D. Van Leeuwen. 2016a. Growth and yield of guar (Cyamopsis tetragonoloba L.) genotypes under different planting dates in the semi-arid Southern High Plains. Am. J. Plant Sci. 7:1246-1258. doi:10.4236/ ajps. 2016.78120

Singla, S., K. Grover, S.V. Angadi, B. Schutte, and D. VanLeeuwen. 2016b. Guar stand establishment, physiology, and yield responses to planting date in southern New Mexico. Agron. J. 108:2289-2300. doi:10.2134/agronj2016.04.0206

Snapp, S.S., S.M. Swinton, R. Labarta, D. Mutch, J.R. Black, R. Leep, J. Nyiraneza, and K. O'Neil. 2005. Evaluating cover crops for benefits, costs and performance within cropping system niches. Agron. J. 97:322-332.

Stafford, R.E. 1982. Yield stability of gaur breeding lines and cultivars. Crop Sci. 22:1009-1011. doi:10.2135/cropsci1982.0011183X0022 $00050027 \mathrm{x}$

Stephens, J.M. 1994. Bean, tepary-Phaseolus acutifolius A. Gray. EDIS Publ. HS55. Univ. of Florida Coop. Ext. Service, Inst. of Food and Agric. Sciences, Gainesville, FL. http://edis.ifas.ufl.edu/mv025 (accessed 31 Aug. 2018).

Subbarao, G.V., Y.S. Chauhan, and C. Johansen. 2000. Patterns of osmotic adjustment in pigeonpea-its importance as a mechanism of drought resistance. Eur. J. Agron. 12:239-249. doi:10.1016/ S1161-0301(00)00050-2

Suyker, A.E., and S.B. Verma. 2009. Evapotranspiration of irrigated and rainfed maize-soybean cropping systems. Agric. For. Meteorol. 149:443-452. doi:10.1016/j.agrformet.2008.09.010

Swaminathan, R., K. Singh, and V. Nepalia. 2012. Insect pests of green gram Vigna radiata (L.) wilczek and their management. In: G. Aflakpui, editor, Agricultural science. IntechOpen Limited, London. doi: $10.5772 / 35176$

Tarawali, S.A., B.B. Singh, M. Peters, and S.F. Blade. 1997. Cowpea haulms as fodder. In: B.B. Singh, D.R. Mohan Raj, K.E. Dashiell, and L.E.N. Jackai, editors, Advances in cowpea research. JIRCAS, Sayce, Devon. p. 313-325.

Thomas, M., J. Robertson, S. Fukai, and M.B. Peoples. 2004. The effect of timing and severity of water deficit on growth, development, yield accumulation and nitrogen fixation of mungbean. Field Crops Res. 86:67-80. doi:10.1016/S0378-4290(03)00120-5

Timko, M.P., J.D. Ehlers, and P.A. Roberts. 2007. Cowpea. In: C. Kole, editor, Genome mapping and molecular breeding in plants, Vol. 3, Pulses, sugar and tuber crops. Springer Verlag, Berlin Heidelberg. p. 49-67. 
Timko, M.P., and B.B. Singh. 2008. Cowpea, a multifunctional legume. In: P.H. Moore and R. Ming, editors, Genomics of tropical crop plants. Springer Science and Business Media, New York. p. 227-258. doi:10.1007/978-0-387-71219-2_10

Tinsley, A.M., J.C. Scheerens, J.O. Alegbejo, F.H. Adan, K.C. Krumhar, L.E. Butler, and M.J. Kopplin. 1985. Tepary beans (Phaseolus acutifolius var. latifolius): A potential food source for African and Middle Eastern cultures. Plant Foods Hum. Nutr. 35:87-101. doi:10.1007/ BF01092124

Tripp, L.D., D.A. Lovelace, and E.P. Boring. 1982. Keys to profitable guar production. Texas Agric. Ext. Serv. Bull. B- 1399. Texas A\&M University System, College Station, TX.

Twidwell, E.K., A. Boe, and K.D. Kephart. 1992. Planting date effects on yield and quality of foxtail millet and three annual legumes. Can. J. Plant Sci. 72:819-827. doi:10.4141/cjps92-098

USDA-ARS. 2016. USDA national nutrient database for standard reference: Release 28. USDA-ARS, Washington, DC.

USDA-ERS. 2017a. Cattle and beef: Statistics and information. USDAERS, Washington, DC.

USDA-ERS. 2017b. Vegetable and pulse data. USDA-ERS, Washington, DC.

USDA-NASS. 2016. Overview of the United States cattle industry. USDA-NASS, Washington, DC.

USDA-NASS. 2017. Crop production. USDA-NASS, Washington, DC.
Vijendra, P.D., K.M. Huchappa, R. Lingappa, G. Basappa, S.G. Jayanna, and V. Kumar. 2016. Physiological and biochemical changes in moth bean (Vigna aconitifolia L.) under cadmium stress. J. Bot. 2016:1-13. doi:10.1155/2016/6403938

Vir, O., and A.K. Singh. 2015. Moth bean [Vigna aconitifolia (Jacq.) Marechal] germplasm: Evaluation for genetic variability and inter characters relationship in hot arid climate of western Rajasthan, India. Legume Res. 38:748-752.

Wagle, P., P.H. Gowda, S.S. Anapalli, K.N. Reddy, and B.K. Northup. 2017. Growing season variability in carbon dioxide exchange of irrigated and rainfed soybean in the southern United States. Sci. Total Environ. 593:263-273. doi:10.1016/j.scitotenv.2017.03.163

Wong, L.J., and C. Parmar. 1997. Cyamopsis tetragonoloba (L.) Taubert. Record from Proseabase. In: I.F. Hanum and L.J.G. van der Maesen, editors, Plant resources of south-east Asia no. 11: Auxiliary plants. Backhuys Publishers, the Netherlands. p. 109-113.

Yu, C.L., D. Hui, T. Johnston, K. Porter, C. Miller, D. Duseja, and F. Tegegne. 2014. Field performance and yield of four pigeonpea varieties in middle Tennessee. Agron. J. 106:2202-2208. doi:10.2134/ agronj14.0280

Zhang, S.R., H. Wang, Z. Wang, Y. Ren, L. Niu, J. Liu, and B. Liu. 2017. Photoperiodism dynamics during the domestication and improvement of soybean. Sci. China Life Sci. 60:1416-1427. doi:10.1007/ s11427-016-9154-x 